\title{
The vertebrate fauna from the "stipite" layers of the Grands Causses (Middle Jurassic, France)
}

\author{
Fabien Knoll ${ }^{1,2 *}$ and Raquel López-Antoñanzas ${ }^{1,3}$ \\ ${ }^{1}$ Departamento de Paleobiología, Museo Nacional de Ciencias Naturales, Consejo Superior de Investigaciones Científicas, Madrid, Spain \\ 2 Palaeontology Research Group, School of Earth, Atmospheric and Environmental Sciences, University of Manchester, Manchester, UK \\ ${ }^{3}$ Palaeobiology and Biodiversity Research Group, School of Earth Sciences, University of Bristol, Bristol, UK
}

\section{Edited by:}

Christopher Carcaillet, Ecole

Pratique des Hautes Etudes, France

Reviewed by:

Lionel Cavin, Muséum d'histoire

Naturelle de la Ville de Genève,

Switzerland

Holly Woodward, Oklahoma State

University Center for Health

Sciences, USA

*Correspondence:

Fabien Knoll, Departamento de Paleobiología, Museo Nacional de

Ciencias Naturales, Consejo

Superior de Investigaciones

Científicas, C/ José Gutiérrez

Abascal 2, 28006 Madrid, Spain

e-mail: knoll@mncn.csic.es
The "stipites" are Bathonian (Middle Jurassic) coals that formed in an everglades-like environment and are now exposed in the Grands Causses (southern France). The vertebrate assemblage of the "stipites" and of the transitional layers to the carbonates in which they are interspersed are reviewed. To date, only small-sized and isolated vertebrate bones, teeth, and scales have been recovered. These record the presence of sharks (Hybodus, Asteracanthus), bony fishes (Lepidotes, Pycnodontiformes, Caturus, Aspidorhynchus), amphibians (Anura, Albanerpetontidae), and reptiles (Crocodylomorpha, Ornithischia, Theropoda). Despite its relatively limited taxonomic diversity, the vertebrate assemblage from the "stipites" and from their associated layers is notable for being one of the few of this age with both terrestrial and marine influences. Compared to other approximately coeval formations in Western Europe, the "stipites" vertebrate assemblage is surpassed in diversity only by those from the British Isles.

Keywords: Chondrichthyes, Lepidotes, Pycnodontiformes, Caturus, Aspidorhynchus, Amphibia, Crocodylomorpha, Dinosauria

\section{INTRODUCTION}

As a fuel source, the coal layers from the Middle Jurassic of the Grands Causses (southern France) have drawn human interest since prehistoric times (Théry et al., 1995) despite their thinness. Mining was already active in the 14th century (Vivier, 1959). Genssane (1776, p. 229) judged the mine of Les Gardies (Revens, Gard) to be profitable (this site was mentioned by latter authors as well, such as Dumas, 1876, pp. 226-227, 722, 1877, pp. 214, 505-506, and Parran, 1856, p. 106). The exploitation reached its apogee during the 19th century, but diminished at the beginning of the 20th century and ceased around the mid-20th century (see e.g., Rouire, 1946).

These deposits were called "stipites" by Brongniart (1829, p. 231) to distinguish them from lignites and other types of coal on the basis of the fact that they are due to "une végétation tout-à-fait différente, composée principalement de cycadées" ("a completely different vegetation, mainly made up of cycads"). This term has long been abandoned and these coals are usually called "lignites," but the analyses presented by Rouire (1928, p. 11, 1946, pp. 327, $353,356,357)$ and Bergounioux and Doubinger (1948, pp. 157, 159) suggest they would actually be much better termed bituminous coals. "Stipites" have formed in coastal swamps of the Massif Central land (see e.g., Fürsich et al., 1995). They are found scattered all over the Grands Causses in thin (always less than a meter) or even diminutive layers (Figure 1). The most significant outcrops are located in the center, in the axis of the "Grands Causses graben," near the Dourbie and Trevezel valleys (municipalities of Revens, Nant, and Causse Bégon) and in the surroundings of La Cavalerie (municipalities of La Cavalerie, Millau, Nant, and La Panouse de Cernon). The "Calcaires à stipites" are Middle to
Late Bathonian in age (Charcosset et al., 1996, 2000; Ciszak et al., 1999).

The presence of fossil invertebrates in these layers was first mentioned by Rouville (1849), whereas Bleicher (1871) was the first to report the occurrence of vertebrate remains. Intensive sampling of a number of sites has been conducted from paleontologists from the Freie Universität Berlin in the 1960s in search of microvertebrates. Nevertheless, only a limited part of the material collected has been published to date (Seiffert, 1969a,b; Kriwet et al., 1997). We have also explored and sampled a variety of sites, which triggered additional publications (Knoll et al., 2013, 2014).

In the present article, we aim at providing a review of the vertebrate remains from the coal and associated marly and clayey layers of the "Calcaires à stipites" with a focus on the best determined components.

\section{VERTEBRATE FAUNA CHONDRICHTHYES \\ Hybodus sp. (Figure 1A)}

Teeth (and, occasionally, dermal denticles) of hybodontiform sharks have been found at a number of sites such as "Les Gardies" (Nant, Aveyron), La Baume (La Panouse de Cernon, Aveyron), and Saint-Martin (Revens, Gard). Although a detailed systematic assessment of this material is definitely needed, the material is believed to be on the whole sufficiently close to the type species of Hybodus, H. reticulatus (Agassiz, 1837), as revised by Maisey (1987), to warrant a generic attribution. It is likely that several species are represented in the Grands Causses. Rees and Underwood (2006, Figure 4.1-3) described as Hybodus sp. a species from approximately coeval beds in Scotland that recall 


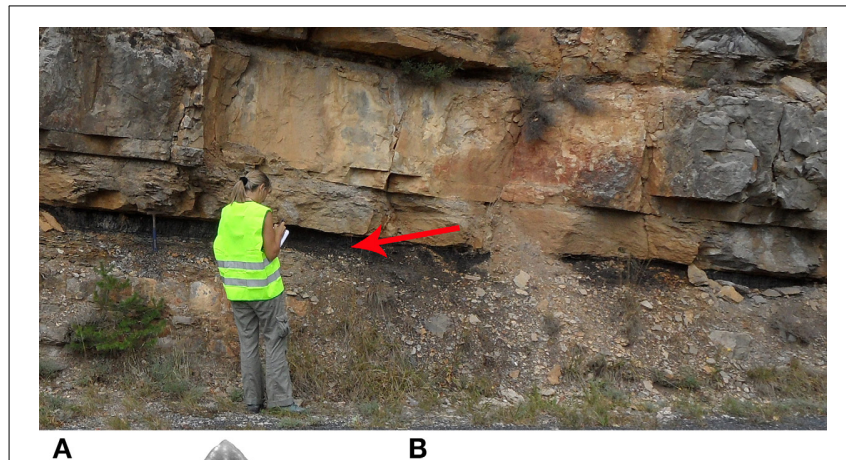

A

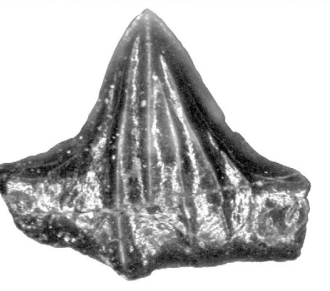

C

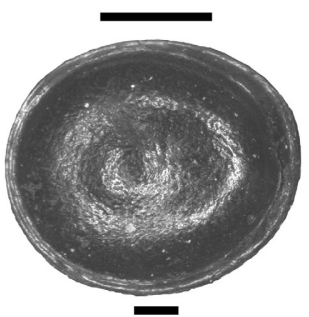

E

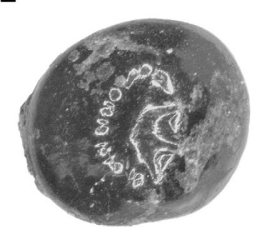

H
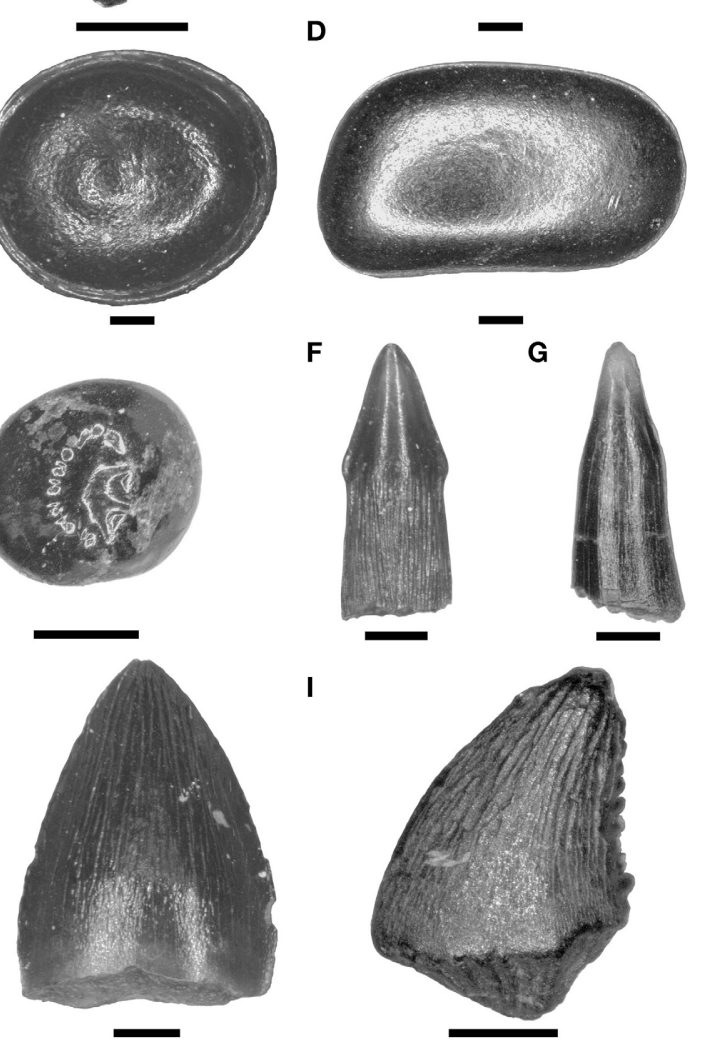

\begin{abstract}
F
\end{abstract}

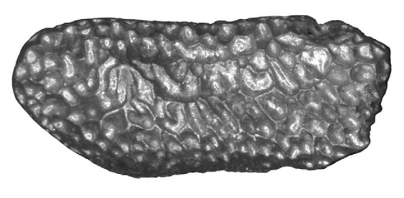

D

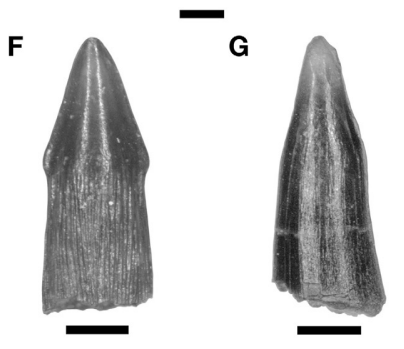

I

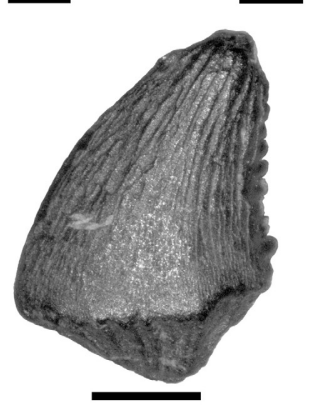

FIGURE 1 | Coal exposure (arrow) at "Les Gardies" (Nant, Aveyron) and representative sample of the teeth found at this site (all housed in the Museum für Naturkunde, Berlin, Germany). (A) Hybodus sp., labial view, (B) Asteracanthus sp., apical view; (C) Lepidotes sp., apical view; (D) Macromesodon sp., apical view; (E) Pycnodontidae indet. (cf. Coelodus sp.), apical view; (F) Caturus sp., lingual view (G) Aspidorhynchus sp., labial view; (H) Atoposauridae indet., labial view; (I) Theropoda indet., lingual view. Scale bars equal $500 \mu \mathrm{m}$.

specimens from the Grands Causses. The genus is well known in the Bathonian of France elsewhere (see e.g., Agassiz, 1837; Bigot, 1896; Coulon, 1903; Priem, 1908a). The genus Hybodus is not a reliable indicator of water salinity.

\section{Asteracanthus sp. (Figure 1B)}

Asteracanthus is a rare taxon, only known by a few teeth in Monplaisir (Le Rozier, Lozère) and "Les Gardies" (Nant, Aveyron). Even so, it is unclear whether only one species, not to mention which, is present. Asteracanthus is one of the most representative sharks from the Bathonian of France (see e.g., Agassiz, 1837; Sauvage, 1867, 1900; Owen, 1869; Bigot, 1896; Coulon, 1903; Priem, 1908a; Ligeron, 2007). The rarity of Asteracanthus in the "stipites" may be either due to taphonomic bias against the preservation of remains over a certain size or the reluctance of the species represented to venture from marine areas into brackish waters, or both.

\section{ACTINOPTERYGII}

\section{Lepidotes sp. (Figure 1C)}

Bleicher (1871, p. 795) first reported the finding of "une dent palatine très-belle de Sargus et des écailles de Lepidotus" ("a very beautiful palatine tooth of Sargus and scales of Lepidotus") (see also Bleicher, 1872a, p. 298, 1872b, p. 409). Ganoid scales and teeth like those described by Mudroch and Thies (1996) and other authors as from Lepidotes have been collected at "Les Gardies," La Baume, Les Moulinets (Nant), Saint-Martin, the lower level of Cornhes (Mostuéjouls, Aveyron) and other sites. The fish scales mentioned by Fürsich et al. (1995, p. 138) possibly belong to the same taxon. The number of species represented in the material from the Grands Causses and whether it incontrovertibly belongs in Lepidotes, i.e., if it is closely related to the Early Jurassic species Lepidotes elvensis (Blainville, 1818), Lepidotes gigas Agassiz, 1832, Lepidotes semiserratus Agassiz, 1836, and Lepidotes bülowianus Jaekel, 1929 (see López-Arbarello, 2012, pp. 26-27), cannot be currently settled. Outside the Causses, Lepidotes has been reported from several Bathonian sites in France (e.g., Agassiz, 1836; Sauvage, 1867, 1880b; Priem, 1908b), but all in all European Middle Jurassic species of Lepidotes remain poorly known.

\section{Pycnodontiformes (Figures 1D,E)}

Teeth of Pycnodontiformes have been collected at sites such as "Les Gardies" and Cornhes. Kriwet et al. (1997) suggested the presence of two genera, the primitive Macromesodon (for prehensile and "molariform" teeth without apical indent) and the more derived Coelodus (for "molariform" teeth with apical indent). However, isolated "molariform" teeth of Pycnodontiformes are difficult to determine with accuracy, being always low and robust (Poyato-Ariza, 2005). Moreover, whereas the type species of Macromesodon is from the Late Jurassic (about 15 myr younger), that of Coelodus is from the Late Cretaceous (about 73 myr younger) (Poyato-Ariza and Wenz, 2002). Gérard (1936, p. 190) listed teeth of Microdon sp. that may come from the Bathonian of Larzac. This genus is now referred to as Proscinetes (see Poyato-Ariza and Wenz, 2002). A diversity of Pycnodontiformes is present in the Bathonian of France outside the Causses, most or all of which probably representing the genus Macromesodon (see e.g., Agassiz, 1836; Sauvage, 1867, 1880a,b; Woodward, 1895; Priem, 1911). The Pycnodontiformes from the Grands Causses probably favored shallow seas. 


\section{Caturus sp. (Figure 1F)}

Specimens that match the teeth attributed to Caturus by Mudroch and Thies (1996) have been collected from "Les Gardies" and the upper layer of Cornhes. Similar material is known from the Late Bajocian site of Larnagol (Lot, France; Kriwet et al., 1997). Caturus is usually considered a marine amiiform. However, the genus is also known from beds of freshwater origin (Bogan et al., 2013, p. 194).

\section{Aspidorhynchus sp. (Figure 1G)}

Kriwet et al. (1997) identified a few blunt conical teeth from "Les Gardies" as Aspidorhynchus sp. The oldest known species of the genus is certainly Bathonian in age: Aspidorhynchus crassus Woodward, 1890. As in the case of Asteracanthus, the presence of such a sea dweller at "Les Gardies" may reveal a strong marine influence.

\section{AMPHIBIA \\ Anura}

Seiffert (1969a) described from "Les Gardies" an omosternum that he identified as from an ancestral Ranidae. This record was critically reappraised by Estes and Reig (1973, p. 29). Sanchiz (1998, pp. 89, 155) considered this specimen as from a non-ranid indeterminate anuran.

No other anuran remains from the "stipites" has been described. However, Sciau et al. (2006, p. 31) alluded to "la découverte dans une grotte des Causses par une équipe de spéléologues, d'un amphibien anoure (Rouire and Rousset, 1973)" ("the discovery in a cave of the Causses by a team of speleologists, of an anuran amphibian (Rouire and Rousset, 1973)") in the 1970s. Rouire and Rousset (1973, p. 26) actually mentioned "les restes d'un amphibien anoure (J. Seiffert)" ("the remains of an anuran amphibian (J. Seiffert)"), but this "amphibien anoure" would have been a distinct find made in a cave of the Trèvezel valley according to Sciau (pers. comm., 2010). Although it is unquestionable that the "stipites" are exposed in some caves of the Grands Causses, it is suspicious to 'stumble upon' a fossil frog in this manner, especially because the vertebrate from the "stipites" are always very small and disarticulated.

\section{Albanerpetontidae}

Seiffert (1969b) described an atlas of urodele from "Les Gardies", which was first recognized as related to Albanerpeton by Estes and Hoffstetter (1976, pp. 297, 316, 321). This specimen is still regarded as the earliest definitive albanerpetontid known (see e.g., Gardner and Böhme, 2008, p. 193, tab. 12.2; Sweetman and Gardner, 2013, p. 320), together with an articular and an axis from a possibly slightly older, Early Bathonian, lens at Snowshill (Gloucestershire, United Kingdom). Gardner and Böhme (2008, p. 193) identified the atlas from "Les Gardies" as from an indeterminate albanerpetontid.

\section{REPTILIA}

\section{Crocodylomorpha (Figure $1 \mathrm{H}$ )}

Teeth of crocodylomorphs are common, in proportion to other vertebrate remains, at specific places such as Les Moulinets and, especially, "Les Gardies." The "petites dents de sauriens" and "dent de petit saurien" ("small teeth of saurians"/"tooth of small saurian”) mentioned by Bleicher (1872a, p. 298, 1872b, p. 409) were probably from crocodylomorphs and so would be the "reptile teeth" observed by Fürsich et al. (1995, p. 138). Kriwet et al. (1997) suggested the presence of a single species at "Les Gardies", close in morphology to atoposaurids as described by Brinkmann (1992) and other authors. Early atoposaurid teeth are also found in abundance in approximately coeval sites, for instance in the Ambondromamy area (Boeny, Madagascar; Flynn et al., 2006).

\section{Dinosauria}

Ornithischia. Kriwet et al. (1997) reported the finding of one ornithischian tooth at "Les Gardies." It is unclear from the text and figure caption if this specimen is among those illustrated by these authors, which are mostly coarsely denticulated crowns devoid of sharp apicobasal ridges on the lateral surface. Kriwet et al. (1997) identified both the tooth from "Les Gardies" and the numerous, allegedly comparable, teeth from Larnagol as from a hypsilophodontid ornithischian. However, continuous improvement of our understanding of ornithischian phylogeny since the late 1990s strongly supports that Hypsilophodon is actually the only member of Hypsilophodontidae (see e.g., Boyd, 2012). For the time being, the affinities of the ornithischian teeth from the Causses described by Kriwet et al. (1997) remains indeterminate. Sciau et al. (2006) described possible ornithopod footprints close to the coal layers at La Verrière (Trèves, Gard) and La Garène (La Roque-Sainte-Marguerite, Aveyron). The single tooth from "Les Gardies" is the only direct remains of Ornithischia from the Bathonian of France.

Theropoda (Figure 1I). Kriwet et al. (1997) reported the finding of a few theropod teeth and tooth fragments at "Les Gardies." The most complete specimens were minuscule unserrated crowns, but portions with chisel-like serrations had also been recovered. Whereas the latter cannot be reasonably identified beyond Theropoda, the former might indicate a Maniraptoriformes (see e.g., Knoll and Ruiz-Omeñaca, 2009; Gianechini et al., 2011). However, the recent description of a pristine Late Jurassic juvenile megalosaurid specimen with some teeth devoid of serrations suggests that the apparition of this character is a more intricate issue than could have been conceived (Rauhut et al., 2012). Theropod footprints were described by Sciau et al. (2006) close to the coal layers at Capelan (Meyrueis, Lozère) and La Garène (La Roque-Sainte-Marguerite, Aveyron). Gand et al. (2007, p. 49) reported an additional theropod footprint near Salles-la-Source (Aveyron). Theropod remains from the Bathonian of France have been mentioned, depicted, and/or described since the beginning of the 19th century and habitually ascribed to Megalosaurus, Poekilopleuron or Dubreuillosaurus (e.g., Caumont, 1828; Eudes-Deslongchamps, 1837; Sauvage, 1900; Mercier, 1937; Rioult, 1978; Buffetaut, 1995; Allain, 2002, 2005). Most of the remains come from the Middle Bathonian Calcaire de Caen, which was deposited in a coastal swamp of the Armorican Massif, not dissimilar to the depositional environment inferred for the "stipites" of the Grands Causses (Rioult, 1963). 


\section{DISCUSSION}

Although relatively scarce, the vertebrate microremains from the coal and associated layers of the Grands Causses (Table 1) are of great interest given their age. Indeed, the best known record of Bathonian microvertebrates is by and large restricted to the United Kingdom (England, mostly, and Scotland; see e.g., Evans, 1991; Metcalf et al., 1992; Evans and Milner, 1994; Metcalf and Walker, 1994; Evans and Waldman, 1996; Evans et al., 2006; and references therein). The British sites were formed under shallow marine conditions (e.g., Stonesfield, Oxfordshire) or in swampy coastal regions (e.g., Kirtlington, Oxfordshire). In contrast to those localities, the Grands Causses are yet to yield definitive remains of salamanders, turtles, lepidosauromorphs, choristoderes, pterosaurs, and therapsids. Although no direct sauropod fossils have been found so far, it should be pointed out that possible footprints from these animals are known at some levels next to coal layers (Sciau et al., 2006; but see discussion in Gand et al., 2007, pp. 48-49) at Capelan (Meyrueis, Lozère), La Verrière (Trèves, Gard), La Garène (La Roque-Sainte-Marguerite, Aveyron), SaintVéran (La Roque-Sainte-Marguerite, Aveyron), Bombes (Nant, Aveyron), Montméjean (Saint-André-de-Vézines, Aveyron), Mas Nau (Millau, Aveyron), Les Crottes (Saint-Georges-de-Luzençon, Aveyron), and Ravin de Raves (Peyreleau, Aveyron). The French Bathonian sauropod record is, in fact, relatively poor as a whole (Sauvage, 1900; Läng, 2008; Buffetaut et al., 2011).

The meager fossil record of the French sites compared to those in the United Kingdom may be, at least in part, because they

Table 1 | Vertebrate fauna from the "stipites" of the Grands Causses.

Chondrichthyes
Hybodontiformes
Hybodus sp.
Asteracanthus sp.
Actinopterygii
Ginglymodi
Lepidotes sp.
Pycnodontiformes
Macromesodon sp.
Pycnodontidae indet. (cf. Coelodus sp.)
Amiiformes
Caturus sp.
Teleostei
Aspidorhynchus sp.
Amphibia
Anura
Anura indet.
Albanerpetontidae
Albanerpetontidae indet.
Reptilia
Crocodylomorpha
Atoposauridae indet.
Dinosauria
Ornithischia indet.
Theropoda indet.

have drawn much less attention. However, genuine observations about the microvertebrates for the Grands Causses can be made. Firstly, the fossil content can vary considerably between different localities as well as between layers within the same site. For instance, crocodiles are the most common remains at "Les Gardies," whereas hybodont sharks prevail in the nearby locality of Saint-Martin. Furthermore, of the two levels examined at Cornhes, one is dominated by ginglymodian fishes and the other by amiiforms. Ecological causes (degree of marine influence) can well account for these faunal dissimilarities. The second remark that can be made is that, crocodile teeth aside, the remains of tetrapods are, as a rule, largely outnumbered by those of fishes sensu lato (either ginglymodians, amiiforms, or hybodonts, depending on the very site and layer). As in British localities (see e.g., Metcalf and Walker, 1994, Figure 19.5), crocodiles are the most common or the only tetrapods present at most sites of the Grands Causses. However, in contrast with the former, there is no evidence of crocodiles other than atoposaurids (which is a minor group of crocodiles in the British Isles) in the latter. A taphonomic bias against 'large' specimens would not satisfactorily explain the lack of non-atoposaurid crocodiles as the teeth of juvenile individuals would still be found. The absence of other crocodiles may, therefore, be genuine, and might be due to the fact that these taxa are either of more marine (teleosaurids) or, conversely, less aquatic (goniopholidids) habits than atoposaurids. At the best known locality ("Les Gardies"), the bulk of the specimens are atoposaurids and ginglymodian fishes. However, the site has also yielded a very small number of a priori mutually exclusive taxa, such as an albanerpetontid amphibian, a bank of freshwater pond inhabitant, together with the teleost Aspidorhynchus, a definite marine taxa. This suggests that a minor part of the remains are allochthonous, that marine flooding took place episodically, or this could just be due to the mixing of taxa from the coal itself and from the transitional beds to the carbonates.

\section{ACKNOWLEDGMENTS}

We are grateful to G. Cuny, J. Gardner, D. Huguet, R. Monteau, J. Philip, B. Sanchiz, L. Sciscio, and D. Schwarz-Wings for various forms of assistance as well as to the reviewers. This is a contribution to the research projects CGL2009-12143 and CGL2011-24829.

\section{REFERENCES}

Agassiz, L. (1832). Untersuchungen über die fossilen Fische der Lias-Formation. Jahrb. Mineral. Geogn. Geol. Petrefaktenk. 3, 139-149.

Agassiz, L. (1836). Recherches sur les Poissons Fossiles. II. Neuchâtel: Petitpierre. Agassiz, L. (1837). Recherches sur les Poissons Fossiles. III. Neuchâtel: Petitpierre. Allain, R. (2002). Discovery of megalosaur (Dinosauria, Theropoda) in the Middle Bathonian of Normandy (France) and its implications for the phylogeny of basal Tetanurae. J. Vert. Paleontol. 22, 548-563. doi: 10.1671/02724634(2002)022[0548:DOMDTI]2.0.CO;2

Allain, R. (2005). The postcranial anatomy of the megalosaur Dubreuillosaurus valesdunensis (Dinosauria Theropoda) from the Middle Jurassic of Normandy, France. J. Vert. Paleontol. 25, 850-858. doi: 10.1671/0272-4634(2005)025[0850: TPAOTM]2.0.CO;2

Bergounioux, F. M., and Doubinger, J. (1948). Observations sur les «Stipites $\gg$ de Balmarelesse (Aveyron). Bull. Soc. Géol. France 18, 153-160.

Bigot, A. (1896). Catalogue des Sélaciens jurassiques du Calvados \& de l'Orne. Bull. Soc. Linnéenne Normandie 10, 7-13. 
Blainville, H.-M. D. de. (1818). "Poissons fossiles," in Nouveau Dictionnaire d'Histoire Naturelle. XXVII, eds J.-B. Biot, L.-A.-G. Bosc, J.-A. Chaptal, H.-M. D. de Blainville, R.-A. de Bonnard, A.-G. Desmarest, et al. (Paris: Deterville), 310-395.

Bleicher, G. (1871). Note sur la faune et la flore de l'horizon lacustre jurassique intermédiaire entre l'oolithe inférieure et l'oolithe moyenne du revers sud et sud-ouest du plateau central. Compt. Rend. Hebdomad. Séances Acad. Sci. 73, 794-796.

Bleicher, G. (1872a). Sur l'horizon lacustre et fluvio-marin de l'oolithe inférieure du midi de la France. Bull. Soc. Géol. France 29, 298-299.

Bleicher, G. (1872b). Essai de paléontologie de l'oolithe inférieure des bords sud et sud-ouest du plateau central. Ann. Mines 1, 401-411.

Bogan, S., Taverne, L., and Agnolin, F. (2013). First Triassic and oldest record of a South American amiiform fish: Caturus sp. from the Los Menucos Group (lower Upper Triassic), Río Negro province, Argentina. Geol. Belg. 16, 191-195.

Boyd, C. A. (2012). Taxonomic Revision of Latest Cretaceous North American Basal Neonithischian Taxa and a Phylogenetic Analysis of Basal Ornithischian Relationships. PhD Dissertation, The University of Texas at Austin, Austin, TX.

Brinkmann, W. (1992). Die Krokodilier-Fauna aus der Unter-Kreide (OberBarremium) von Uña (Provinz Cuenca, Spanien). Berliner Geowiss. Abh. E 5, $\mathrm{i}-\mathrm{v}+1-123$.

Brongniart, A. (1829). Tableau des Terrains qui composent l'Ecorce du Globe. Paris: F.G. Levrault.

Buffetaut, E. (1995). Dinosaures de France. Orléans: Bureau de Recherches Géologiques et Minières.

Buffetaut, E., Gibout, B., Launois, I., and Delacroix, C. (2011). The sauropod dinosaur Cetiosaurus OWEN in the Bathonian (Middle Jurassic) of the Ardennes (NE France): insular, but not dwarf. Carnets Géol. 6, 149-161. doi: $10.4267 / 2042 / 43897$

Caumont, A. de. (1828). Essai sur la Topographie géognostique du Département du Calvados. Caen: T. Chalopin.

Charcosset, P., Ciszak, R., Peybernès, B., and Garcia, J.-P. (1996). Modalités séquentielles de la transgression bathonienne sur le $\ll$ Seuil cévenol 》 (Grands Causses). Compt. Rend. Acad. Sci. Sér. 323, 419-426.

Charcosset, P., Combes, P.-J., Peybernes, B., Ciszak, R., and Lopez, M. (2000). Pedogenic and karstic features at the boundaries of Bathonian depositional sequences in the Grands Causses area (southern France): stratigraphic implications. J. Sediment. Res. 70, 255-264. doi: 10.1306/2DC4090F-0E47-11D78643000102C1865D

Ciszak, R., Peybernès, B., Thierry, J., and Fauré, P. (1999). Synthèse en termes de stratigraphie séquentielle du Dogger et de la base du Malm dans les Grands Causses. Géol. France 4, 45-58.

Coulon, L. (1903). Les poissons fossiles du Musée d'Histoire naturelle d'Elbeuf avec notes spéciales sur les espèces de la Seine-Inférieure. Bull. Soc. Etude Sci. Nat. Elbeuf 21, 99-162.

Dumas, E. (1876). Statistique géologique, minéralogique, métallurgique et paléontologique du Département du Gard. Deuxième Partie. Paris: A. Bertrand.

Dumas, E. (1877). Statistique géologique, minéralogique, métallurgique et paléontologique du Département du Gard. Troisième Partie. Paris: A. Bertrand.

Estes, R., and Hoffstetter, R. (1976). Les Urodèles du Miocène de La Grive-SaintAlban (Isère, France). Bull. Mus. Natl. Hist. Nat. Sci. Terre 57, 297-344.

Estes, R., and Reig, O. A. (1973). "The early fossil record of frogs: a review of the evidence," in Evolutionary Biology of the Anurans, ed J. L. Vial (Columbia: University of Missouri Press), 11-63.

Eudes-Deslongchamps, J.-A. (1837). Mémoire sur le Poekilopleuron Bucklandii, grand saurien fossile, intermédiaire entre les crocodiles et les lézards; découvert dans les carrières de la Maladrerie, près Caen, au mois de juillet 1835. Caen: A. Hardel.

Evans, S. E. (1991). Small reptiles and amphibians from the Forest Marble (Middle Jurassic) of Dorset. Proc. Dorset Nat. Hist. Archaeol. Soc. 113, 201-202.

Evans, S. E., Barrett, P. M., Hilton, J., Butler, R. J., Jones, M. E. H., Liang, M.-M., et al. (2006). "The Middle Jurassic vertebrate assemblage of Skye, Scotland," in Ninth International Symposium on Mesozoic Terrestrial Ecosystems and Biota, eds P. M. Barrett and S. E. Evans (London: The Natural History Museum), 36-39.

Evans, S. E., and Milner, A. R. (1994). "Middle Jurassic microvertebrate assemblages from the British Isles," in In the Shadow of the Dinosaurs: Early Mesozoic Tetrapods, eds N. C. Fraser and H.-D. Sues ( Cambridge: Cambridge University Press), 303-321.
Evans, S. E., and Waldman, M. (1996). Small reptiles and amphibians from the Middle Jurassic of Skye, Scotland. Mus. North. Ariz. Bull. 60, 219-226.

Flynn, J. J., Fox, S. R., Parrish, J. M., Ranivoharimanana, L., and Wyss, A. R. (2006). Assessing diversity and paleoecology of a Middle Jurassic microvertebrate assemblage from Madagascar. N.M. Mus. Nat. Hist. Sci. Bull. 37, 476-489.

Fürsich, F. T., Freytag, S., Röhl, J., and Schmid, A. (1995). Palaeoecology of benthic associations in salinity-controlled marginal marine environments: examples from the Lower Bathonian (Jurassic) of the Causses (southern France). Palaeogeogr. Palaeoclimatol. Palaeoecol. 113, 135-172. doi: 10.1016/00310182(95)00072-T

Gand, G., Demathieu, G., and Montenat, C. (2007). Les traces de pas d'amphibiens, de dinosaures et autres reptiles du Mésozoïque français: inventaire et interprétations. Palaeovertebrata 35, 1-149.

Gardner, J. D., and Böhme, M. (2008). "Review of the Albanerpetontidae (Lissamphibia), with comments on the paleoecological preferences of European Tertiary albanerpetontids," in Vertebrate Microfossil Assemblages: Their Role in Paleoecology and Paleobiogeography, eds J. T. Sankey and S. Baszio (Bloomington: Indiana University Press), 178-218.

Genssane, A. de. (1776). Histoire naturelle de la Province de Languedoc, Partie minéralogique et géoponique. I. Montpellier: Rigaud, Pons, \& Compagnie.

Gérard, C. (1936). Les fossiles aaléniens du sud-est de la France conservées dans les collections de l'Institut de Géologie de Nancy. Bull. Mens. Soc. Sci. Nancy 9, 175-192.

Gianechini, F. A., Makovicky, P. J., and Apesteguía, S. (2011). The teeth of the unenlagiine theropod Buitreraptor from the Cretaceous of Patagonia, Argentina, and the unusual dentition of the Gondwanan dromaeosaurids. Acta Palaeontol. Pol. 56, 279-290. doi: 10.4202/app.2009.0127

Jaekel, O. (1929). Lepidotus und Leptolepis aus dem oberen Lias von Dobbertin, Mecklenburg. Mitt. Mecklenb. Geol. Landesanst. 38, 13-25.

Knoll, F., Cuny, G., Mojon, P.-O., and López-Antoñanzas, R. (2014). New palaeontological data from the organic-rich layers of the Bathonian of the Grands Causses (France). Proc. Geol. Assoc. 125, 312-316. doi: 10.1016/j.pgeola.2014. 04.003

Knoll, F., Cuny, G., Mojon, P.-O., López-Antoñanzas, R., and Huguet, D. (2013). A new vertebrate-, ostracod-, and charophyte-bearing locality in the Middle Jurassic of the Grands Causses (southern France). Proc. Geol. Assoc. 124, 525-529. doi: 10.1016/j.pgeola.2012.09.001

Knoll, F., and Ruiz-Omeñaca, J. I. (2009). Theropod teeth from the basalmost Cretaceous of Anoual (Morocco) and their palaeobiogeographical significance. Geol. Mag. 146, 602-616. doi: 10.1017/S0016756809005950

Kriwet, J., Rauhut, O. W. M., and Gloy, U. (1997). Microvertebrate remains (Pisces, Archosauria) from the Middle Jurassic (Bathonian) of southern France. N. Jahrb. Geol. Paläontol. Abh. 206, 1-28.

Läng, E. (2008). Les Cétiosaures (Dinosauria, Sauropoda) et les Sauropodes $d u$ Jurassique Moyen: Révision Systématique, Nouvelles Découvertes et Implications Phylogénétiques. I-II. Thèse de doctorat, Muséum National d'Histoire Naturelle, Paris.

Ligeron, J.-M. (2007). Découverte de plusieurs espèces nouvelles de poissons fossiles et autres reptiles marins, dans le Jurassique moyen ardennais. Bull. Soc. Hist. Nat. Ardennes 96, 48-55.

López-Arbarello, A. (2012). Phylogenetic interrelationships of ginglymodian fishes (Actinopterygii: Neopterygii). PLoS ONE 7:e39370. doi: 10.1371/journal.pone.0039370

Maisey, J. G. (1987). Cranial anatomy of the Lower Jurassic shark Hybodus reticulatus (Chondrichthyes: Elasmobranchii), with comments on hybodontid systematics. Am. Mus. Novit. 2878, 1-39.

Mercier, J. (1937). Notes paléontologiques. Bull. Soc. Linnéenne Normandie 9, 33-36.

Metcalf, S. J., Vaughan, R. F., Benton, M. J., Cole, J., Simms, M. J., and Dartnall, D. L. (1992). A new Bathonian (Middle Jurassic) microvertebrate site within the Chipping Norton Limestone Formation at Hornsleasow Quarry, Gloucestershire. Proc. Geol. Assoc. 103, 321-342. doi: 10.1016/S00167878(08)80129-0

Metcalf, S. J., and Walker, R. J. (1994). "A new Bathonian microvertebrate locality in the English Midlands," in In the Shadow of the Dinosaurs: Early Mesozoic Tetrapods, eds N. C. Fraser and H.-D. Sues (Cambridge: Cambridge University Press), 322-331. 
Mudroch, A., and Thies, D. (1996). Knochenfischzähne (Osteichthyes, Actinopterygii) aus dem Oberjura (Kimmeridgium) des Langenbergs bei Oker (Norddeutschland). Geol. Palaeontol. 30, 239-265.

Owen, R. (1869). Description of a great part of a jaw with the teeth of Strophodus medius, Ow., from the Oolite of Caen in Normandy. Geol. Mag. 6, 193-196. doi: $10.1017 /$ S0016756800159035

Parran, A. (1856). Note sur les formations secondaires des environs de SaintAffrique (Aveyron). Ann. Mines 10, 91-114.

Poyato-Ariza, F. J. (2005). Pycnodont fishes: morphologic variation, ecomorphologic plasticity, and a new interpretation of their evolutionary history. Bull. Kitakyushu Mus. Nat. Hist. Hum. Hist. 3, 169-184.

Poyato-Ariza, F. J., and Wenz, S. (2002). A new insight into pycnodontiform fishes. Geodiversitas 24, 139-248.

Priem, F. (1908a). Etude des Poissons Fossiles du Bassin Parisien. Paris: Masson \& Cie.

Priem, F. (1908b). Etude sur le genre Lepidotus. Ann. Paléontol. 3, 1-19.

Priem, F. (1911). Etude des Poisons fossiles du Bassin parisien (supplément). Ann. Paléontol. 6, 3-173.

Rauhut, O. W. M., Foth, C., Tischlinger, H., and Norell, M. A. (2012). Exceptionally preserved juvenile megalosauroid theropod dinosaur with filamentous integument from the Late Jurassic of Germany. Proc. Natl. Acad. Sci. U.S.A. 109, 11746-11751. doi: 10.1073/pnas.1203238109

Rees, J., and Underwood, C. J. (2006). Hybodont sharks from the Middle Jurassic of the Inner Hebrides, Scotland. Trans. R. Soc. Edinb. Earth Sci. 96, 351-363. doi: $10.1017 /$ S0263593300001346

Rioult, M. (1963). Le Calcaire de Caen, dépôt de rivage du Bathonien normand. Bull. Soc. Linnéenne Normandie 3, 119-141.

Rioult, M. (1978). Ecosystèmes Continentaux Mésozö̈ques de Normandie. Caen: Université de Caen.

Rouire, J., and Rousset, C. (1973). Causses, Cévennes, Aubrac. Paris: Masson \& Cie.

Rouire, L. (1928). Lignites du Larzac. Mém. Soc. Lett. Sci. Arts Aveyron 22, 1-18.

Rouire, L. (1946). Lignites du Larzac. Mém. Soc. Lett. Sci. Arts Aveyron 26, 317-366.

Rouville, P.-G. de. (1849). Sur les houilles du Larzac. Extr. Proc.-Verb. Séances Acad. Sci. Lett. Montpellier 3, 31-34.

Sanchiz, B. (1998). Handbuch der Paläoherpetologie. IV. Munich: F. Pfeil.

Sauvage, H.-E. (1867). Catalogue des Poissons des Formations secondaires $d u$ Boulonnais. Boulogne-sur-Mer: C. Aigre.

Sauvage, H.-E. (1880a). Notes sur les poissons fossiles (suite). Bull. Soc. Géol. France $8,451-462$.

Sauvage, H.-E. (1880b). Synopsis des poissons et des reptiles des terrains jurassiques de Boulogne-sur-Mer. Bull. Soc. Géol. France 8, 524-547.
Sauvage, H.-E. (1900). Note sur les poissons et les reptiles du Jurassique inférieur du département de l'Indre. Bull. Soc. Géol. France 28, 500-504.

Sciau, J., Bécaud, M., and Gand, G. (2006). Présence de Dinosaures Théropodes, et Probablement, d'Ornithopodes et de Sauropodes, dans le Marais Maritime $d u$ Bajocien-Bathonien des Causses. Millau: Association Paléontologique des Causses.

Seiffert, J. (1969a). Sternalelement (Omosternum) eines mitteljurassischen Anuren von SE-Aveyron/Südfrankreich. Z. Zool. Syst. Evolutionsforsch. 7, 145-153. doi: 10.1111/j.1439-0469.1969.tb00852.x

Seiffert, J. (1969b). Urodelen-Atlas aus dem obersten Bajocien von SE-Aveyron (Südfrankreich). Paläontol. Z. 43, 32-36. doi: 10.1007/BF02987925

Sweetman, S. C., and Gardner, J. D. (2013). A new albanerpetontid amphibian from the Barremian (Early Cretaceous) Wessex Formation of the Isle of Wight, southern England. Acta Palaeontol. Pol. 58, 295-324. doi: 10.4202/app. 2011.0109

Théry, I., Grilt, J., Vernet, J.-L., Meignent, L., and Maury, J. (1995). First use of coal. Nature 373, 480-481. doi: 10.1038/373480a0

Vivier, E. (1959). Mines de charbon en Rouergue au XIVe siècle. Proc.-Verb. Soc. Lett. Sci. Arts Aveyron 37, 15-20.

Woodward, A. S. (1890). A synopsis of the fossil fishes of the English Lower Oolites. Proc. Geol. Assoc. 11, 285-306. doi: 10.1016/S0016-7878(90)80030-4

Woodward, A. S. (1895). Catalogue of the Fossil Fishes in the British Museum (Natural History). III. London: Taylor and Francis.

Conflict of Interest Statement: The authors declare that the research was conducted in the absence of any commercial or financial relationships that could be construed as a potential conflict of interest.

Received: 17 April 2014; accepted: 27 July 2014; published online: 02 September 2014. Citation: Knoll F and López-Antoñanzas R (2014) The vertebrate fauna from the "stipite" layers of the Grands Causses (Middle Jurassic, France). Front. Ecol. Evol. 2:48. doi: 10.3389/fevo.2014.00048

This article was submitted to Paleoecology, a section of the journal Frontiers in Ecology and Evolution.

Copyright (c) 2014 Knoll and López-Antoñanzas. This is an open-access article distributed under the terms of the Creative Commons Attribution License (CC BY). The use, distribution or reproduction in other forums is permitted, provided the original author(s) or licensor are credited and that the original publication in this journal is cited, in accordance with accepted academic practice. No use, distribution or reproduction is permitted which does not comply with these terms. 